\title{
Full Transparency of Politicians' Actions Does Not Increase the Quality of Political Representation
}

\author{
David Stadelmann, ${ }^{*} \dagger$ Marco Portmann ${ }^{\ddagger}$ and Reiner Eichenberger ${ }^{\dagger}, \ddagger$
}

\begin{abstract}
We identify the impact of transparency in political decision-making on the quality of political representation with a difference-in-difference strategy. The quality of political representation is measured by the observed divergence of parliamentary decisions from revealed voter preferences on identical issues. We show that full transparency of votes of individual politicians does not decrease divergence from voter preferences.
\end{abstract}

Keywords: Transparency, quality of political decisions, representation, parliament, individual votes, referenda.

\section{INTRODUCTION}

Transparency in political decision-making is often proposed as a remedy to failures of the political agency. Transparent individual decisions are thought to foster accountability and align the interests of politicians/agents with voters/principals. Many countries have implemented open government reforms (Carey 2008) and grant public access to recorded individual votes, i.e. votes with the names of politicians voting for and against a proposal.

However, a small number of recent theoretical contributions (e.g. Fox 2007; Prat 2005) discuss potential negative consequences of transparency in political decisionmaking on the quality of policy outcomes and representation of voter preferences, particularly when actions of politicians such as individual votes are recorded and made publicly available. Empirical evidence of the causal effects of full transparency

We would like to thank Mark Stucki from the Swiss Parliamentary Services for providing information on the video coverage of Upper House sessions and for a productive e-mail exchange.

*University of Bayreuth, Universitätsstraße 30, Bayreuth, Germany; e-mail: david.stadelmann@unibayreuth.de

†CREMA - Center for Research in Economics, Management and the Arts, Südstrasse 11, CH-8008 Zürich, Switzerland

‡University of Fribourg, Bd. de Pérolles 90, Fribourg, Switzerland; e-mail: marco.portmann@unifr.ch, reiner.eichenberger@unifr.ch

(C) The Experimental Research Section of the American Political Science Association 2014 
on political decision-making is currently scarce at best. Therefore, the present paper attempts to fill this gap using an especially informative natural setting.

Voters in Switzerland reveal their policy preferences in referenda. Parliamentarians vote on identical policy issues as voters in referenda. Thus, we can directly confront referendum results with parliamentary decisions in the Lower and Upper House of the Swiss Parliament to obtain a direct measure of divergence, i.e. an inverse measure for the quality of politicians' decisions with respect to revealed voter preferences. Since the winter session of 2006, publicly available video streams of the Upper House's sessions allow identifying votes of individual politicians, instead of only aggregate decisions prior to 2006. In the Lower House, final individual votes of politicians have been recorded electronically and published before and after the year 2006. Thus, we exploit a difference-in-difference setting to identify the effect of increased transparency of individual votes on the quality of political decisions with respect to voter preferences. Empirical results indicate that making it easier to identify individual votes and actions of politicians does not necessarily improve the quality of representation in terms of aligning political decisions and voter preferences more closely.

We present the empirical identification strategy in Section 2, assess the causal effect of transparency on the quality of political representation in Section 3, and conclude in Section 4.

\section{INSTITUTIONAL SETTING AND IDENTIFICATION STRATEGY}

We exploit a unique quasi-natural institutional setting in Switzerland to identify the effect of transparency of politicians' votes in Parliament on the quality of political decisions with respect to voter preferences.

Two houses, the Lower House (National Council/Nationalrat) and the Upper House (Council of States/Ständerat) make up the Swiss Parliament. Both houses have the same amount of political power and decide on the same legislative and constitutional amendments. Parliamentary proposals have to be approved by the majority of members in each house in order to be adopted. Members of the Lower House are elected under a system of proportional representation with open party lists and the members of the Upper House are elected by plurality rule. ${ }^{1}$ The aggregated results of the final policy decisions of both houses are published.

In an effort toward open government reforms, video streams of the parliamentary sessions have been made publicly available on the internet since the winter session of 2006. Thus, both the discussion and individual final votes of members of the Upper House can be identified as politicians vote by raising their hands. Before 2006,

\footnotetext{
${ }^{1}$ This institutional difference between the houses remained stable over time and, thus, plays no role for our identification strategy, as will become apparent.
} 
identifying individual votes in the Upper House after the session was impossible. Importantly, parliamentarians did not decide themselves on the publication of the recordings but neither did they impede the Parliamentary Services from releasing them. Greater transparency in the Upper House was constantly demanded by different proponents, including certain party officials, the media, and other groups. ${ }^{2}$ The individual final votes of politicians in the Lower House have been recorded electronically and have been made publicly available since 1995 .

The legislative and constitutional proposals of Parliament are not directly enacted. Before proposals are enacted, Swiss voters are given the opportunity to demand a referendum and they can propose constitutional amendments by initiatives (Frey 1994; Portmann et al., 2012). ${ }^{3}$ Referendum results reflect voter preferences with regard to constitutional and legislative proposals (Schneider et al., 1981). Voters and parliamentarians decide on identical proposals with exactly the same wording. Thus, the parliamentary decisions can be matched and directly compared with revealed voter preferences in referenda (Carey and Hix 2013; Hersch and McDougall 1988; Matsusaka 2010).

We take the absolute difference between the voter yes-share in a referendum and the yes-share of politicians in their parliamentary decisions in the respective house as a natural and inverse measure of the quality of political decisions, i.e. we observe divergence from voter preferences in the two houses. The absolute difference to the voter yes-share of each house represents a meaningful measure of preference representation (Golder and Stramski 2010). Different levels of divergence for the two houses are due to the electoral system, which remained unchanged over the period analyzed, and thus makes the Lower House a control group for the Upper House, where transparency of individual decisions changed. Divergence from voter preferences is associated with adverse consequences, particularly in relation to candidates' election prospects (Stadelmann et al., 2013b).

Similar to other countries, Swiss parliamentarians rely on common tools (e.g. surveys, personal experience, etc.) to infer voter preferences as they are only revealed after parliamentary decisions which is essential when evaluating legislative shirking (Garret 1999). Therefore, our results are likely to generalize to decisions in countries where policy preferences of voters are not directly observable from referendum results.

Our dataset consists of 91 referenda that cover a broad range of different topics. The corresponding, identical parliamentary decisions of each of the two houses

\footnotetext{
${ }^{2}$ Evaluations of final individual votes of the Upper House were a topic ahead of the 2011 elections (e.g. NZZ am Sonntag, No. 35, 28.08.2011, p. 15) and after reports of miscounting of votes in the Upper House, analyses of the recordings were prominently discussed.

${ }^{3}$ By collecting 50,000 signatures, any legislative amendment may be subject to a referendum. For constitutional amendments, referenda are mandatory. 100,000 are sufficient for an initiative and politicians are required to vote on initiatives. Stadelmann et al. (2013a) provide further details on the institutional background.
} 


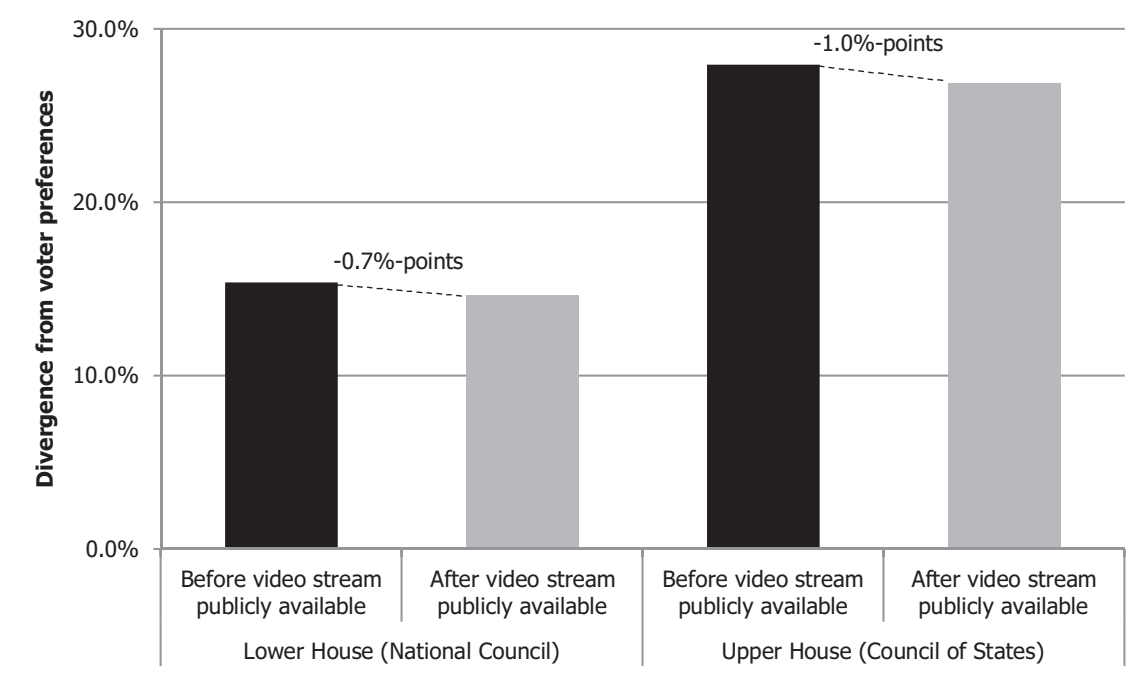

Figure 1

The Effect of Full Transparency of Individual Votes on the Divergence of Politicians From Voter Preferences

took place during the three legislatures $\left(46^{\text {th }}, 47^{\text {th }}, 48^{\text {th }}\right)$ from 1999 to 2011 , leading to a total of 182 observations. The data are available from the Swiss Parliamentary Services.

The identification strategy follows directly from the institutional setting under examination: For the entire period of analysis, we observe actual divergence from revealed voter preferences of the Lower and the Upper House. From 2006 onwards (during the third year of the $47^{\text {th }}$ legislature, over a year prior to elections), the individual votes of members of the Upper House were made transparent by the introduction of video streams. Individual votes in the Lower House were made public throughout the period of analysis. Thus, we employ a standard differencein-difference strategy to identify the causal impact of increased transparency on the quality of political decisions with respect to voter preferences.

\section{RESULTS}

Figure 1 and its accompanying Table 1 convey the central effect of increased transparency on divergence from voter preferences. Before the public availability of video streams (prior to the winter session of 2006), the average divergence from voter preferences was 15.4\%-points in the Lower House and 27.9\%-points in the Upper House. After the public availability of video streams, the average divergence was $14.7 \%$-points in the Lower House and 26.9\%-points in the Upper House. Thus, the reduction in divergence corresponds to $0.7 \%$-points for the Lower and $1.0 \%$ points for the Upper House. The difference-in-difference identifies the causal effect 


\section{Table 1}

Descriptive Results-The Effect of Full Transparency on the Divergence From Voter Preferences

\begin{tabular}{lccc}
\hline & $\begin{array}{c}\text { Before availability } \\
\text { of video streams }\end{array}$ & $\begin{array}{c}\text { After public availability } \\
\text { of video streams }\end{array}$ & Difference \\
\hline Divergence from voter & $0.154^{* * *}$ & $0.147^{* * *}$ & -0.007 \\
preferences of Lower House & $(0.016)$ & $(0.025)$ & $(0.030)$ \\
Divergence from voter & $0.279^{* * *}$ & $0.269^{* * *}$ & -0.010 \\
preferences of Upper House & $(0.019)$ & $(0.027)$ & $(0.033)$ \\
\hline Difference & $0.125^{* * *}$ & $0.122^{* * *}$ & $-\mathbf{0 . 0 0 3}$ \\
& $(0.025)$ & $(0.037)$ & $\mathbf{( 0 . 0 4 5 )}$ \\
\hline
\end{tabular}

Notes: $* * *,{ }^{*}$, and $*$ indicate significance levels of below $1 \%$, between 1 and $5 \%$, and between 5 and $10 \%$, respectively.

of the increase in transparency which corresponds to a meager and insignificant $0.3 \%$-points lower divergence. These results do not provide systematic support to the common claims that increased transparency generally improves the quality of political representation.

Table 2, specification (1) confirms the baseline results from Figure 1 with a dummy for the Upper House, a dummy indicating the public availability of video streams, and an interaction between the two to identify the effect of increased transparency. Specification (2) shows that even in the short term (i.e. the 30 matched parliamentary/referenda decisions made directly before and after the introduction of full transparency) no significant impact due to transparency is observed, and the point estimate of the interaction effect turns positive. ${ }^{4}$

Transparency in political decisions may be particularly important when conflicts of interest arise. Therefore, we focus on a subsample where business associations and trade unions issue different voting recommendations. However, we still do not observe any significant impact due to the existence of public video stream availability (specification 3). Similarly, when left and right political parties issue different recommendations (specification 4), greater transparency does not play any significant role in decreasing divergence either. ${ }^{5}$

Making the decision processes in politics more transparent may have its disadvantages when voters have priors for controversial issues. Initiatives are usually more controversial than proposals brought forward by Parliament. In specification (5), which focuses on initiatives only, we find a positive but not significant differencein-difference effect. The importance of a policy issue in a referendum is partly

\footnotetext{
${ }^{4}$ When reducing the set to the $47^{\text {th }}$ legislature (when video streams were made public) the interaction effect is also positive and not significant. When including the full $45^{\text {th }}$ legislature and first results for the current $49^{\text {th }}$ legislature, the effect of more transparency remains insignificant.

${ }^{5}$ We employ official recommendations of the largest Swiss Business Federation "economiesuisse" and the "Federation of Swiss Trade Unions" (specification 3) as well as the Swiss People's Party and the Social Democrats (specification 4) as recorded by the Parliamentary Services.
} 
Table 2

Difference-in-Difference—Full Transparency of Individual Votes Due to Video Stream Availability Does Not Reduce Divergence of Politicians From Voter Preferences

\begin{tabular}{|c|c|c|c|c|c|c|c|}
\hline & $\begin{array}{c}\text { (1) } \\
\text { Full } \\
\text { sample }\end{array}$ & $\begin{array}{c}\text { (2) } \\
30 \text { referenda } \\
\text { before/after }\end{array}$ & $\begin{array}{c}\text { (3) } \\
\text { Conflict business } \\
\text { vs. unions }\end{array}$ & $\begin{array}{l}\text { (4) } \\
\text { Conflict left } \\
\text { vs. right }\end{array}$ & $\begin{array}{l}\text { (5) } \\
\text { Initiatives } \\
\text { only }\end{array}$ & $\begin{array}{l}\text { (6) } \\
\text { High turnout } \\
\text { referenda }\end{array}$ & $\begin{array}{c}(7) \\
\text { Full } \\
\text { sample }\end{array}$ \\
\hline Upper House & $\begin{array}{l}0.1257^{* * *} \\
(0.0251)\end{array}$ & $\begin{array}{l}0.1317^{* * *} \\
(0.0329)\end{array}$ & $\begin{array}{l}0.1213^{* * *} \\
(0.0319)\end{array}$ & $\begin{array}{l}0.1371^{* * *} \\
(0.0287)\end{array}$ & $\begin{array}{l}0.1037^{* * *} \\
(0.0260)\end{array}$ & $\begin{array}{l}0.1178^{* * *} \\
(0.0400)\end{array}$ & $\begin{array}{l}0.1257^{* * *} \\
(0.0227)\end{array}$ \\
\hline Video publicly available & $\begin{array}{r}-0.0072 \\
(0.0297)\end{array}$ & $\begin{array}{c}0.0298 \\
(0.0389)\end{array}$ & $\begin{array}{c}0.0275 \\
(0.0482)\end{array}$ & $\begin{array}{r}-0.0163 \\
(0.0311)\end{array}$ & $\begin{array}{r}-0.0079 \\
(0.0347)\end{array}$ & $\begin{array}{r}-0.0594 \\
(0.0406)\end{array}$ & $\begin{array}{c}0.0039 \\
(0.0287)\end{array}$ \\
\hline (Upper House) * (Video Publicly Available) & $\begin{array}{r}-0.0032 \\
(0.0442)\end{array}$ & $\begin{array}{c}0.0073 \\
(0.0567)\end{array}$ & $\begin{array}{c}0.0050 \\
(0.0744)\end{array}$ & $\begin{array}{r}-0.0225 \\
(0.0471)\end{array}$ & $\begin{array}{c}0.0018 \\
(0.0503)\end{array}$ & $\begin{array}{c}0.0346 \\
(0.0622)\end{array}$ & $\begin{array}{r}-0.0032 \\
(0.0414)\end{array}$ \\
\hline Turnout in referendum & & & & & & & $\begin{array}{l}0.0044^{* * *} \\
(0.0014)\end{array}$ \\
\hline Is initiative & & & & & & & $\begin{array}{c}-0.1061^{* * *} \\
(0.0199)\end{array}$ \\
\hline Conflict between left and right parties & & & & & & & $\begin{array}{r}-0.0085 \\
(0.0288)\end{array}$ \\
\hline Intercept & $\begin{array}{l}0.1537^{* * *} \\
(0.0163)\end{array}$ & $\begin{array}{l}0.1148^{* * *} \\
(0.0156)\end{array}$ & $\begin{array}{l}0.1367^{* * *} \\
(0.0210)\end{array}$ & $\begin{array}{l}0.1525^{* * *} \\
(0.0186)\end{array}$ & $\begin{array}{l}0.1134^{* * * *} \\
(0.0190)\end{array}$ & $\begin{array}{l}0.1681^{* * *} \\
(0.0269)\end{array}$ & $\begin{array}{c}0.0049 \\
(0.0591)\end{array}$ \\
\hline$R^{2}$ & 0.166 & 0.287 & 0.148 & 0.179 & 0.193 & 0.177 & 0.291 \\
\hline No. of observations & 182 & 60 & 106 & 154 & 84 & 88 & 182 \\
\hline
\end{tabular}

$1 \%$ and $5 \%$, and between $5 \%$ and $10 \%$, respectively. 
reflected by turnout. Specification (6) considers a subset of referenda which received a relatively high turnout. While we do not find any significant effect of increased transparency, the point estimate is with 3.5\%-points relatively large and again positive which suggests, if anything, higher divergence for potentially controversial proposal due to transparency.

Finally, specification (7) looks at the full sample and includes additional control variables. Again, we do not find any significant interaction effect of video availability on divergence of politicians from voter preferences.

\section{CONCLUSIONS}

Pundits of fully transparent political processes suggest that transparency fosters greater accountability of politicians towards their voters. We exploit a natural setting to test this claim and analyze the effect of transparency of political processes on the quality of political decisions. We use the observed divergence of politicians from voter preferences as an inverse and direct measure of quality. The introduction of publicly available video streams of the debates and votes of the Swiss Parliament in 2006 allows identifying individual votes of politicians in the Upper House. Final individual votes have been published before and after 2006 for the Lower House of Parliament. Thus, we use a difference-in-difference setting to identify the causal effect of transparency on divergence from voter preferences.

Empirical results show that full transparency does not necessarily increase the quality of political representation in the Upper House compared to the Lower House. The point estimates of the impact of increased transparency of individual actions on divergence from voter preferences are sometimes even positive. Thus, there is no clear support for the common belief that transparency always increases accountability. We highlight, however, that the way transparency was achieved, may not prove powerful enough to change the behavior of politicians towards voters. While, in principle, all decisions were transparent after 2006 and could be analyzed ex-post, gathering information from videos might represent an obstacle to the simple and fast dissemination into political debates. Nevertheless, politicians might be expected to adapt their behavior towards voters given that they can be evaluated prior to elections. We recognize that we cannot provide direct evidence on the power of the change in transparency such that there remains the potential that the increase in transparency was too weak to affect the quality of representation. However, our results may generalize to countries where greater transparency is publicly declared but relevant information for voters is not easily available.

While our empirical results seem unexpected, they are generally consistent with predictions of recent and elaborated models (Fox 2007; Prat 2005) which highlight the potential negative impacts of transparency of individual votes on the quality of political representation. Studies from other areas where video streams/surveillance 
was introduced also cast doubt on the effectiveness of such measures (see Stutzer and Zehnder 2013 for a review of video surveillance).

\section{REFERENCES}

Carey, J. M. 2008. Legislative Voting and Accountability (Cambridge Studies in Comparative Politics). New York: Cambridge University Press.

Carey, J. M., and Hix, S. 2013. District Magnitude and Representation of the Majority's Preferences: A Comment and Reinterpretation. Public Choice 154 (1-2): 139-48.

Fox, J. 2007. Government Transparency and Policymaking. Public Choice 131 (1-2): 23-44.

Frey, B. S. 1994. Direct Democracy: Politico-Economic Lessons from Swiss Experience. American Economic Review 84 (2): 338-42.

Garrett, T. A. 1999. A Test of Shirking Under Legislative and Citizen Vote: The Case of State Lottery Adoption. Journal of Law and Economics 42 (1): 189-208.

Golder, M., and Stramski, J. 2010. Ideological Congruence and Electoral Institutions. American Journal of Political Science 54 (1): 90-106.

Hersch, P. L., and McDougall, G. S. 1988. Voting for 'Sin' in Kansas. Public Choice 57 (2): 127-39.

Matsusaka, J. G. 2010. Popular Control of Public Policy: A Quantitative Approach. Quarterly Journal of Political Science 5 (2): 133-67.

Portmann, M., Stadelmann, D., and Eichenberger, R. 2012. District Magnitude and Representation of the Majority's Preferences: Quasi-Experimental Evidence from Popular and Parliamentary Votes. Public Choice 151 (3-4): 585-610.

Prat, A. 2005. The Wrong Kind of Transparency. American Economic Review 95 (3): 862-77.

Schneider, F., Pommerehne, W. W., and Frey, B. S. 1981. Politico-Economic Interdependence in a Direct Democracy: The Case of Switzerland. In Contemporary Political Economy: Studies on the Interdependence of Politics and Economics (pp. 231-248). Douglas A. Hibbs and Heino Fassbender, eds., Amsterdam, The Netherlands: North Holland.

Stadelmann, D., Portmann, M., and Eichenberger, R. 2013a. Quantifying Parliamentary Representation of Constituents' Preferences with Quasi-Experimental Data. Journal of Comparative Economics 41 (1): 170-80.

Stadelmann, D., Portmann, M., and Eichenberger, R. 2013b Voters Elect Politicians Who Closely Matched Their Preferences. Economics Bulletin 33 (2): 1001-9.

Stutzer, A., and Zehnder, M. 2013. Is Camera Surveillance an Effective Measure of Counterterrorism? Defence and Peace Economics 24 (1): 1-14. 